University of Miami Law School University of Miami School of Law Institutional Repository

2005

\title{
On Legal Pragmatism: Where Does "the Path of the Law" Lead Us?
}

Susan Haack

University of Miami School of Law, shaack@law.miami.edu

Follow this and additional works at: https://repository.law.miami.edu/fac_articles

Part of the Jurisprudence Commons, Law and Philosophy Commons, and the Legal History Commons

\section{Recommended Citation}

Susan Haack, On Legal Pragmatism: Where Does "the Path of the Law" Lead Us?, 50 Am. J. Juris. 71 (2005).

This Article is brought to you for free and open access by the Faculty and Deans at University of Miami School of Law Institutional Repository. It has been accepted for inclusion in Articles by an authorized administrator of University of Miami School of Law Institutional Repository. For more information, please contact library@law.miami.edu. 


\title{
ON LEGAL PRAGMATISM: WHERE DOES "THE PATH OF THE LAW" LEAD US?
}

\author{
SUSAN HAACK
}

\begin{abstract}
When I think ... of the law, I see a princess mightier than she who once wrought at Bayeux, eternally weaving into her web dim figures of the ever-lengthening past,-figures too dim to be noticed by the idle, too symbolic to be interpreted except by her pupils, but to the discerning eye disclosing every painful step and every world-shaking contest by which mankind has worked and fought its way from savage isolation to organic social life. ${ }^{1}$
\end{abstract}

This all started with a deceptively simple-sounding pair of questions: "What is legal pragmatism, and is there anything worthwhile in it?" It will end, however, with some not-so-simple answers: "What is called "legal pragmatism' today is very different from the older style of legal pragmatism traditionally associated with Oliver Wendell Holmes; and there is much that is worthwhile in the conception of law revealed by reading Holmes's 'The Path of the Law' in the light of the philosophy of the classical pragmatist tradition, though less in contemporary legal neo-pragmatism." As I articulate and defend these answers, my reflections on the varieties of pragmatism -philosophical and legal, old and new-will be wrapped around my exploration of the meaning of "The Path of the Law" and the strengths and weaknesses of its arguments.

\section{LEGAL PRAGMATISM TODAY}

Of late, the word "pragmatism" appears in the titles of books, chapters, and articles on legal philosophy often enough to convey the impression that there must be some kind of renaissance of pragmatism going on among legal scholars. ${ }^{2}$ When you look at the contents of those books and articles, though, you are likely to find yourself more than a little confused about just what this apparent renaissance is a renaissance of.

Pragmatism, you will read, is simply a "general aversion to theory" (Atiyah, 1987) $;$ " it is "solving legal problems using every tool that comes to hand,

1. Holmes, "The Law," address delivered to the Suffolk Bar Association Dinner, February 5th, 1885; reprinted in The Holmes Reader, ed. Julius J. Marke (Dobbs Ferry, NY: Oceana, Docket Series, 1955; second edition, 1964), 62-3, 63.

2. Indeed, a symposium in Southern Califormia Law Review 63 (1990) was entitled "The Renaissance of Pragmatism in American Legal Thought."

3. P. S. Atiyah, Pragmatism and Theory in English Law (London: Stevens and Sons, 1987), 5 . 
including precedent, tradition, legal text, and social policy-[and] renounc[ing] the entire project of providing a theoretical foundation for constitutional law" (Farber, 1988); ${ }^{4}$ an "understand[ing] that what we see always depends upon our viewpoint, and that understanding others is frequently a matter of attempting to recreate the standpoint from which they view events" (Hantzis, 1988); " "a realistic expression of the recognition that metatheoretical claims to truth are philosophically indefensible" (Patterson, 1990); "freedom from theory-guilt" (Grey, 1990); " a kind of exhortation about theorizing ... not say[ing] things that lawyers and judges do not know, but rather remind[ing] lawyers and judges of what they already believe but often fail to practice" (Smith, 1990); "looking at problems concretely, without illusions, with a full awareness of the limitations of human reason, with a sense of the "localness" of human knowledge, the difficulty of translations between cultures, the unattainability of "truth"" (Posner, 1990); ${ }^{9}$ the view that "practice is not undergirded by an overarching [sic] set of immutable principles, or by an infallible or impersonal method" (Fish, 1990); ${ }^{10}$ "a synthesis of contextualism and instrumentalism" (Grey, 1991);" "antifoundationalism, and ... social optimism" (Hoy, 1991); "the distinctly American philosophical movement begun by C. S. Peirce and William James, developed by John Dewey, and recently espoused by Richard Rorty ... a substantive position ... [which] yields relativism about truth and justice" (Warner, 1993); "'an eclectic, result-

4. Daniel A. Farber, "Legal Pragmatism and the Constitution," Minnesota Law Review 72 (1988) 1331-78, 1332.

5. Catharine Wells Hantzis, "Legal Innovation Within the Wider Intellectual Tradition: The Pragmatism of Oliver Wendell Holmes, Jr.," Northwestern University Law Review 82 (1988) 541-95, 595.

6. Dennis Patterson, "Law's Pragmatism: Law as Practice and Narrative," Virginia Law Review 76 (1990) 937-98, 996.

7. Thomas C. Grey, "Hear the Other Side: Wallace Stevens and Pragmatist Legal Theory," Southern California Law Review 63 (1990) 1569-95, 1569.

8. Steven D. Smith, “The Pursuit of Pragmatism," Yale Law Journal 100 (1990) 409-49,

411. (Smith acknowledges that his is a non-standard interpretation of legal pragmatism.)

9. Richard A. Posner, "A Pragmatist Manifesto," Problems of Jurisprudence (Cambridge, Mass.: Harvard University Press, 1990), 465.

10. Stanley Fish, "Almost Pragmatism: Richard Posner's Jurisprudence," University of Chicago Law Review 57 (1990) 1447-75, 1464.

11. Thomas C. Grey, "What Good is Legal Pragmatism?" in Pragmatism in Law and Society, ed. Michael Brint and William Weaver (Boulder, Colorado: Westview Press, 1991), 9$27,15$.

12. David Hoy, "Is Legal Originalism Compatible with Philosophical Pragmatism?" in Brint and Weaver, Pragmatism in Law and Society [supra, n, 11], 343-58, 344.

13. Richard Warner, "Why Pragmatism? The Puzzling Place of Pragmatism in Critical Theory," University of Illinois Law Review 3 (1993) 535-63, 537. Later he adds, rather 
oriented, historically-minded antiformalis[m]" (Luban, 1996); ${ }^{14}$ "a critique of essentialist/conceptualist formalism, and an admonition to avoid excessive theorizing or abstractions," urging "more dialogue, traditionalism, attention to context, and the middle way" (Tamanaha, 1997); ${ }^{15}$ the idea that "a satisfactory theory of adjudication for lawyers must enable lawyers to predict what courts will do" (Leiter, 1997-8); "16 "a philosophical discourse that is general, hysteric, external, practical, and progressive, and beside it a legal antecedent discourse (that of Holmes) that is professional, obsessive, internal, theoretical, and conservative" (Alberstein, 2002) ${ }^{17}$ "a disposition to base action on facts and consequences rather than on conceptualisms, generalities, pieties, and slogans ... reject[ing] moral, legal and political theory when offered to guide legal ... decisionmaking" (Posner, 2003); 18 "an extension of skepticism, ultimately rooted in Greek sophism" (Leaf, 2003); ${ }^{19}$ an acknowledgment that "devotion to theory may be just as damaging and unfruitful as devotion to traditional legal formalism" (Weaver, 2003); ${ }^{20}$ "an eclectic and self-reflective stance about both theory and methods; a recognition of a plurality of contingent 'truths' and 'meanings' that are grounded in concrete experience rather than absolute or fundamental truths; and avoidance of dichotomies and uni-dimensional approaches and an explicit incorporation of democratic ideals in both the outcomes (goals) of public policy and in the way that policy analysis is itself conducted"' (Schneider and Ingram, 2003), ${ }^{21}$ the view that "the validity of consensus building depends not on its theoretical

confusingly, that " $[\mathrm{t}] \mathrm{he}$ views of legal pragmatists are generally inconsistent with Peircean pragmatism." Id. at 543.

14. David Luban, "What's Pragmatic About Legal Pragmatism?" Cardozo Law Review 18 (1996) 43-73, 44.

15. Brian Z. Tamanaha, Realistic Socio-Legal Theory: Pragmatism and a Social Theory of Law (Oxford: Clarendon Press, 1997), 35.

16. Brian Leiter, "Naturalism and Pragmatism in Legal Theory," section III of "Rethinking Legal Realism: Toward a Naturalized Jurisprudence," Virginia Law Review 76 (1997-98) 267-315, 285-6.

17. Michal Alberstein, Pragmatism and Law: From Philosophy to Dispute Resolution (Dartmouth: Ashgate, 2002), 2.

18. Richard A. Posner, Law, Pragmatism, and Democracy (Cambridge, Mass.: Harvard University Press, 2003), 3.

19. Murray J. Leaf, "Pragmatic Legal Norms," in Renascent Pragmatism: Studies in Law and Social Science, ed. Alfonso Morales (Aldershot, Hants: Ashgate, 2003), 72-89, 73.

20. William G. Weaver, "The 'Democracy of Self-Devotion': Oliver Wendell Holmes, Jr., and Pragmatism," in Morales, Renascent Pragmatism [supra, n. 19], 3-30, 4.

21. Anne Larson Schneider and Helen Ingram, "The Pragmatic Policy Analyst," in Morales, Renascent Pragmatism [supra, n.19], 156-79, 157. 
possibility of achieving 'win-win' solutions, but on the efficacy of consensus building in its application" (Coglianese, 2003). ${ }^{22}$

What we have here is not simply-as perhaps we do with "realism" and "positivism"23 - a divergence of the legal meaning(s) of a word from its philosophical meaning(s); it is a desperately confusing scholarly mare's nest. Rather than tackling it directly, I shall first sketch the origins of the classical pragmatist tradition in philosophy, and Oliver Wendell Holmes's place in this story; and then articulate the complex argument of "The Path of the Law," and explore what this famous lecture of Holmes's might have to teach us now. With this work in hand, it should be possible to dispel at least some of the current confusions.

\section{The Pragmatist Tradition In Philosophy}

Besides its use(s) in legal theory, the word "pragmatism" has, of course, both an everyday and a technical philosophical use-well, I say "of course"; but (of course!) the two are often run together, and the philosophical use is ambiguous to say the least.

In the eighteenth century, to describe someone as a pragmatist was to say that he was a practical, busy person. By the late nineteenth century, and apparently for much of the twentieth, the word had acquired a pejorative tone, as "pragmatic" came to mean "officious, opinionated," and "pragmatism," correspondingly, "officious meddlesomeness." By now, the meaning of these words has shifted once again: in ordinary speech today, "pragmatism" usually connotes concern with expediency rather than principle, with "matters of fact, often to the exclusion of intellectual or artistic matters; practical as opposed to idealistic." 24

22. Gary Coglianese, "Does Consensus Work? A Pragmatic Approach to Public Participation in the Regulatory Process," in Morales, Renascent Pragmatism [supra, n. 19], 18095, 189.

23. "Realism" has not one but umpteen philosophical meanings (see Susan Haack, "Realisms and Their Rivals: Recovering Our Innocence," Facta Philosophica 4 (2002) 67-88); but they share the idea that something-truth, reality, moral or epistemic or etc., values, or whatever-is, in some sense, independent of us. And "positivism," as used philosophically, is understood sometimes in more and sometimes in less expansive ways.

24. I am relying on the Oxford English Dictionary Online (2005)-which offers as an example of the nineteenth-century usage this, from Charles Cowden Clarke, Shakespeare's Characters: Chiefly Those Subordinate (1863; New York: AMS Press, 1974), 209: “[Malvolio]is a moral teetotaller, a formalist, a pragmatist ..."; Dictionary of the English Language (Philadelphia: David Mackay, 1885); A Standard Dictionary of the English Language (London: Funk and Wagnalls, 1897); The Concise Oxford Dictionary of Current English (Oxford: Clarendon Press, revised fourth edition, 1959); and Webster's Ninth New Collegiate Dictionary (Springfield, MA: Merriam-Webster's, 1991), from which the current meaning quoted in the text is taken. 
In philosophy, "classical pragmatism" refers to the late nineteenth-century movement in American philosophy of which the first moment was Charles Sanders Peirce's pragmatic maxim, which characterized meaning in terms of the "pragmatic" (practical, experiential) consequences of a concept's applying; and by extension to later work in the spirit of this tradition. "Neopragmatism" refers to the late twentieth-century development associated with Richard Rorty's attacks on foundationalism, essentialism, and scientism.

It was William James who, in 1898, first put the word "pragmatism" into philosophical currency, and who made this style of philosophy famous. ${ }^{25}$ But James acknowledged that the key idea had arisen in discussions with Peirce at the Metaphysical Club in Cambridge, Mass., in the very early 1870s. Indeed, some seeds of pragmatism are already discernable in Peirce's 1868 series of anti-Cartesian papers and his 1871 review of Fraser's edition of the works of George Berkeley, ${ }^{26}$ and Peirce had articulated the pragmatist conception of meaning, quite unmistakably, in a paper published in 1878: "How to Make Our Ideas Clear,"27 which he would later describe as "a little paper expressing some of the opinions I had been urging [at the Metaphysical Club] under the name of pragmatism." However, he explained, when he published this paper he had deliberately avoided the word "pragmatism," because "in those medieval times, I dared not in type use an English word to express an idea unrelated to its received meaning"28 -i.e., presumably, its then received meaning, "officious meddlesomeness." ${ }^{29}$ Peirce took his bows as

25. William James, "Philosophical Conceptions and Practical Results," University Chronicle (University of California, Berkeley) 1 (September 1898) 287-310; reprinted in James, Pragmatism, ed. Frederick Burkhardt and Fredson Bowers (Cambridge, Mass.: Harvard University Press, 1975), 255-70.

26. Charles Sanders Peirce, Collected Papers, ed. Charles Hartshorne, Paul Weiss, and Arthur Burks (Cambridge, Mass.: Harvard University Press, 1931-58), 5.213-357 (1868) and 8.7-38 (1871). [References to the Collected Papers are by volume and paragraph number. With published papers, the date given in parentheses is the year of publication; with unpublished papers, it is the year the paper was written.]

27. Peirce, Collected Papers [supra, n.26], 5.388-410 (1878).

28. Peirce, Collected Papers [supra, n.26], 5.13 (c.1906). (It was the editors of the Collected Papers, and not Peirce himself, who supplied "The Pragmatic Maxim" and "Applications of the Pragmatic Maxim" as subtitles of the relevant sections of "How to Make Our Ideas Clear.")

29. So far as I have been able to determine, Peirce first used the word "pragmatism" in print in his August 1899 review of John Fiske, Through Nature to God (reprinted in Charles Sanders Peirce: Contributions to the Nation, ed. Kenneth Laine Ketner and James Edward Cook (Lubbock, Texas: Texas Tech Press, 1975-79), 2: 210-211); he used the word again in his January 1901 review of two books by Anthony Ashley, Earl of Shaftesbury (ibid, 3: 261); and, finally, describes his own view as "pragmatism" in his entry under "Pragmatic and Pragmatism" in J. M. Baldwin, Dictionary of Philosophy and Psychology (New York: MacMillan, 1902) 2: 321-2, reprinted in Collected Papers [supra, n.26], 5.1-5. 
founder of pragmatism in a lecture at Harvard in 1903; though the dove he had sent forth in 1878 had never returned to him, he wrote, "of late quite a brood of young ones have been fluttering about, from the feathers of which I might fancy that mine had found a brood." 30

Both Peirce and James wrote that they saw pragmatism as a method, an approach to philosophical questions focused on pragmatic consequences, not as a body of philosophical doctrine; and pragmatist philosophy was from the beginning extraordinarily various. It encompassed a vast range of interests, areas, and angles-as the young Italian philosopher Giovanni Papini emphasized when he likened pragmatism to a great hotel, where all the guests pass through the same corridor, but each works alone in his own room on the questions that especially interest him. But a second and less benign kind of variousness was also present from the beginning, in differences between Peirce's understanding of the Pragmatic Maxim and James' construal: Peirce stressed the connection between "pragmatic" and Kant's "pragmatische," meaning, roughly, "experiential," as contrasted with "a priori"; James stressed the connection between "pragmatic" and the Greek "praxis," "action," as contrasted with theory.

These differences became more marked as Peirce moved towards a realist, subjunctive formulation of the maxim (according to which to say, for example, that a diamond is hard, means not just that if it is rubbed against other substances it will scratch them, but that if it were rubbed against them it would scratch them) ${ }^{31}$ and as James developed his doctrine of the Will to Believe, and then found himself struggling, not entirely successfully, to distinguish this doctrine from the pragmatism-as-method he took himself to share with Peirce. By 1905-though writing warmly of James and even of the radical British pragmatist F. C. S. Schiller-Peirce was complaining about the "merciless abuse" to which his word had been subjected in the literary journals, abuse so egregious that he was ready "to kiss his child good-by," and "to announce the birth of the word 'pragmaticism,' which is ugly enough to be safe from kidnappers." 32

In view of the potential for fissure already present in the differences between Peirce's and James's elaborations of the pragmatic method, and the potential for confusion with this or that specific philosophical doctrine, not to mention the shifting meaning of the word in ordinary usage, the subsequent

30. Peirce, Collected Papers [supra, n.26], 5.17 (1903).

31. Peirce, Collected Papers [supra, n.26], 5.453 (1905): "the question is, not what did happen, but ... whether that diamond would resist an attempt to scratch it." In 1878, Peirce admits, he had "endeavored to gloze over this point," or had perhaps been unclear in his own mind. ("Realist," as used here, contrasts with "nominalist"; Haack, "Realisms and Their Rivals" [supra, n.23], pp.78-80.)

32. Peirce, Collected Papers [supra, n.26], 5.414 (1905). 
fragmentation of philosophical pragmatisms is hardly surprising. And once Rorty got hold of James, pragmatism took a sharply radical turn: what could be further from Peirce's observations that the truth "is SO, whether you, or I, or anybody believes it is so or not," and that "every man is fully convinced that there is such a thing as truth, or he would not ask any question" 33 than Rorty's cheerful boast that he "does not have much use for the notion of 'objective truth'," or his breezy assurance that truth is "entirely a matter of solidarity"? ${ }^{34}$

Wide-ranging as their philosophical interests were-Peirce's in logic, semiotic, metaphysics, cosmology, theory of inquiry, philosophy of science, and so on, James's in metaphysics, philosophy of religion, philosophy of mind, ethics, and so forth - neither had much to say about the philosophy of law. Though recently it seems to have been Rorty's style of neo-pragmatism that has been most warmly welcomed by legal commentators, traditionally it is Oliver Wendell Holmes who has been seen as the originator of the pragmatist tradition in legal theory. Elsewhere, I have traced the evolution of philosophical pragmatism from Peirce to Rorty and beyond; ${ }^{35}$ here, I shall begin with Holmes's place in the classical-pragmatist chapter of this story.

$$
* * *
$$

Holmes, we know, attended some of Peirce's lectures at the Lowell Institute in $1866 ; ;^{36}$ and he seems to have been involved in the Metaphysical Club even before the beginning. In 1868 James had written to him from Berlin, proposing "[w]hen I get home let's establish a philosophical society to have regular meetings and discuss none but the very tallest and broadest questions- to be composed of none but the very topmost of Boston manhood," and predicting that this might "grow into something very important after a sufficient number of years." 37 The evidence suggests, however, that though Holmes participated

33. Peirce, Collected Papers [supra, n.26], 2.135 (1902), 5.211 (1903).

34. Richard Rorty, "Trotsky and the Wild Orchids," Common Knowledge 1.3 (1992) 14053, 141; Objectivity, Relativism and Truth (Cambridge: Cambridge University Press, 1991), 32.

35. Susan Haack, "Pragmatism, Old and New," Contemporary Pragmatism 1.1 (2004) 1 41; reprinted in Pragmatism, Old and New, ed. Susan Haack and Robert Lane (Amherst, NY: Prometheus Books, 2006).

36. Mark DeWolfe Howe, Justice Oliver Wendell Holmes: The Shaping Years (Cambridge, Mass.: Belknap Press of Harvard University Press, 1957), 251, citing Philip P. Wiener, Evolution and the Founders of Pragmatism (Cambridge, Mass.: Harvard University Press, 1949; Philadelphia: University of Pennsylvania Press, 1972), 75. Peirce's (unpublished) lectures were entitled "The Logic of Science and Induction."

37. Quoted by Max Fisch, "Was There a Metaphysical Club in Cambridge?", in Studies in the Philosophy of Charles Sanders Peirce, ed. G. Moore and Richard Robin (Amherst, Mass.: University of Massachusetts Press, 1964), 5-32, 4, citing Ralph Barton Perry, The Thought and Character of William James (Boston: Little, Brown, and Company, 1935), 1: 508; also found 
early on, he was rarely present at meetings of the club after the winter of 1871-2; at any rate, in 1927-at which point he was the only surviving member-he told Charles Hartshorne (one of the young editors of Peirce's Collected Papers) that he "soon dropped out of the band." 38

In 1906, reminiscing in print about the origins of pragmatism, Peirce testifies to the influence of two other attorneys who also participated: Nicholas St. John Green, "a skillful lawyer, ... a disciple of Jeremy Bentham," who urged the importance of applying Alexander Bain's definition of belief as "that upon which a man is prepared to act"-from which, Peirce continues, "pragmatism is scarce more than a corollary"; and Chauncey Wright, "something of a philosophical celebrity in those days ... our boxing-master whom we ... used to face to be severely pummeled." While he also writes warmly of Holmes - "Mr Justice Holmes will not, I believe, take it ill that we are proud to remember his membership"39-Peirce says nothing specific about his influence. Holmes himself would later write that he thought he "learned more from Chauncey Wright and St. John Green" than from Peirce; and express reservations about Hartshorne's prediction that the publication of Peirce's papers would be an important philosophical event. ${ }^{40}$

And-not surprisingly, given that the then-common meaning of "pragmatism" was so off-putting, and that The Common Law and "The Path of the Law" were both published before James had put the word into circulation in its special philosophical sense-Holmes never officially allied himself with pragmatism. Indeed, when James introduced his pragmatism to the philosophical world Holmes, like many readers, had trouble distinguishing it from the Will to Believe-which he described in a letter to Frederick Pollock as "an amusing humbug." 41 So when, much later, he read an early anthology of Peirce's work, ${ }^{42}$ what struck him was that Peirce's "reasoning in

in Liva Baker, The Justice from Beacon Hill: The Life and Times of Oliver Wendell Holmes (New York: HarperCollins, 1991), 214-5.

38. Max Fisch, "Was There a Metaphysical Club in Cambridge?" [supra, n.37], 22.

39. Peirce, Collected Papers [supra, n.26], 5.12 (c.1906).

40. Holmes to Charles Hartshorne, August 25th, 1927; my source is Fisch, "Was There a Metaphysical Club in Cambridge?" [supra, n.37], 10-11.

41. Holmes-Pollock Letters: The Correspondence of Mr. Justice Holmes and Sir Frederick Pollock, 1874-1932, ed. Mark DeWolfe Howe (Cambridge, Mass.: Harvard University Press, 1941), 1:139 (June 17, 1908).

42. Chance, Love, and Logic, ed. Morris R. Cohen (1923; Lincoln, Nebraska: University of Nebraska Press, 1998). Peirce, however, apparently didn't like the Will to Believe doctrine much more than Holmes did; at any rate, the year after The Will to Believe, dedicated "to my old friend, Charles Sanders Peirce," was published, he is found writing rather pointedly of the "Will to Learn" (Collected Papers [supra, n.26], 5.583 (1898)). Holmes may have been misled by the title of Peirce's paper, "The Doctrine of Evolutionary Love," included in this early anthology, 
the direction of religion \&c., seems ... to reflect what he wants to believe-despite his devotion to logic." ${ }^{43}$ He was, however, apparently much impressed by Dewey, of whose Experience and Nature ${ }^{44}$ he wrote in 1931 that "although [it] is incredibly ill written ... [s] o methought God would have spoken had He been inarticulate but keenly desirous to tell you how [the cosmos] was." 45

In 1942, Max Fisch described Holmes's The Common Law as "full of the spirit of pragmatism from the ringing sentences in which its theme is announced-'the life of the law has not been logic; it has been experience' - on to the end",;6 in 1949 Philip Weiner entitled chapter 8 of his Evolution and the Founders of Pragmatism, "Evolutionary Pragmatism in Holmes's Theory of the Law",47 and many commentators have noted the apparent parallel between Holmes's presentation of the "prediction theory" in "The Path of the Law" (1896), and Peirce's statement of the pragmatic maxim in "How to Make Our Ideas Clear":

Consider what effects, that might conceivably have practical bearings, we conceive the object of our conception to have. Then our conception of these effects is the whole of our conception of the object. [Peirce] $]^{48}$

... a legal duty so called is nothing but a prediction that if a man does or omits certain things he will be made to suffer in this or that way by judgment of the court; - and so of a legal right. [Holmes] $]^{49}$

a paper which in fact articulates the cosmological theory Peirce calls "agapism," positing the evolution of order from chaos by "affinity."

43. "The Holmes-Cohen Correspondence," ed. F. M. Cohen, Journal of the History of Ideas 9 (1948), 34.

44. John Dewey, Experience and Nature (New York: W. W. Norton, 1929).

45. Holmes-Pollock Letters [supra, n.41], 2:287 (May 15, 1931).

46. Max Fisch, "Justice Holmes, the Prediction Theory of the Law, and Pragmatism" (1942), in Peirce, Semeiotic, and Pragmatism: Essays by Max Fisch, ed. Kenneth Laine Ketner and Christian J. W. Kloesel (Bloomington, IN: Indiana University Press, 1986), 6-18, 8. This observation of Fisch's should not be taken as suggesting that the pragmatists were hostile to logic. James, to be sure, was no logician; but (as Fisch would have been well aware) Peirce was a major figure in the history of modern logic, developing a unified propositional and predicate calculus by 1880 -the year after Gottlob Frege's Begriffsschrift (1879; English translation by Terrell Ward Bynum, Conceptual Notation and Related Articles, Oxford: Clarendon Press, 1972), but quite independently of Frege's work.

47. Wiener, Evolution and the Founders of Pragmatism [supra, n.36].

48. Peirce, Collected Papers [supra, n.26], 5.401 (1878).

49. Holmes, "The Path of the Law," Harvard Law Review 10 (1896) 457-78, reprinted in The Collected Works of Justice Holmes, ed. Sheldon M. Novick (Chicago: Chicago University Press, 1995), vol.3, 391-406, 391. All page references in the text are to this version. 
Indeed, Fisch once suggested that, rather than Holmes's idea being a special case of Peirce's, Peirce's pragmatic maxim may have been a kind of extrapolation of this strand in Holmes's thinking ${ }^{50}$ (as, it seems, J. L. Austin's theory of performative utterances was a kind of extrapolation of H. L. A. Hart's concept of operative speech). ${ }^{51}$ For Holmes had expressed something like this idea as early as 1872, in a note in the American Law Review in which, summarizing and endorsing Pollock's critique of John Austin's Lectures on Jurisprudence, he had written:

[A]s is clear from numerous instances of judicial interpretation of statutes and of constitutions in this country, ... in a civilized state it is not the will of the sovereign that makes lawyers' law, even when that is its source, but what a body of subjects, namely the judges, by whom it is enforced, say is his will. ... The only question for lawyers is, how will the judges act? ? $^{52}$

Fisch's conjecture oversimplifies, however. As I noted earlier, some protopragmatist ideas were already apparent in Peirce's work before this note of Holmes's; moreover, the philosophy of law Holmes had developed by the time of "The Path of the Law" turns out to be far subtler and more sophisticated than the label "prediction theory" suggests. So we need to look more closely.

\section{ThE PATH OF THE LAW: OR, You TAKe THE LOW RoAD AND I'LL TAKE THE HIGH ROAD}

Holmes's elegantly aphoristic style has tempted many readers to assume that this or that memorable phrase in "The Path of the Law" encapsulates the whole; but summary descriptions like "the prediction theory," "the Bad Man theory," or "the revolt against formalism," and one-dimensional pictures of Holmes simply as early precursor of the legal-realist movement or of the lawand-economics approach, as anti-theoretical, etc., aren't really adequate to the depth, or the inner complexities, of his jurisprudence.

Inner complexities-or inner contradictions? The opening lines of "The Path of the Law" seem eminently down-to-earth and practical: "When we study law we are not studying a mystery but a well-known profession. We are studying what we shall want in order to appear before judges, or to advise people in such a way as to keep them out of court. ... The object of our study

50. Fisch, "Justice Holmes, the Prediction Theory of the Law, and Pragmatism" [supra, n.46], 12.

51. J. L. Austin, How to Do Things With Words (Cambridge: Harvard University Press, 1962), 7, n.1. My thanks to William Widen for drawing this footnote to my attention.

52. Oliver Wendell Holmes, American Law Review 6 (1872) 723; reprinted in Novick, The Collected Works of Justice Holmes [supra, n.49], vol. 1, 294-7; the quotation is from p.295. 
... is ... the prediction of the incidence of the public force through the instrumentality of the courts" ("The Path of the Law," p.391). But Holmes's closing lines take us very far from mundane practical concerns about when the bailiff may be expected at the door: "happiness, I am sure from having known many successful men, cannot be won simply by being counsel for great corporations and having an income of fifty thousand dollars. An intellect great enough to win the prize needs other food besides success. The remoter and more general aspects of the law are those which give it universal interest. It is through them that you ... connect your subject with the universe, and catch an echo of the whole, a glimpse of its unfathomable process, a hint of the universal law" (405-6). Some may be inclined simply to ignore these concluding sentences, or to write them off as nothing more than an embarrassing effusion of late-nineteenth-century purple prose; but this would be a mistake. There is a larger picture here, a larger picture in which Holmes's briskly practical opening and his visionary closing are seamlessly integrated.

As he climbs the steep path from the mundane specificities that concern the working attorney to the intellectual aspirations of the legal theorist, Holmes's arguments begin negatively. His concern is to dispel some common illusions: Law, he argues, cannot be identified with Morality; does not transcend the specific practices of the many and various legal systems; and bears little resemblance to a set of first principles or axioms from which correct decisions may be deduced.

Unjust laws have been enforced; and though terms like "duty," "right," "malice," "intent," etc., play a role both in moral and in legal discourse, their meanings diverge in the two contexts (nor are all legitimate moral demands legally enforced, or legally enforceable). So, to begin to get a clear view of the law as distinct from morality, we need to set ethical considerations firmly aside: Holmes advises taking the perspective of a working attorney advising a hypothetical client who doesn't give a damn what's right, but just wants to know what's legal. Thus: "If you want to know the law and nothing else, you must look at it as a bad man, who cares only for the material consequences which such knowledge enables him to predict, and not as a good one, who finds his reasons for conduct, whether inside the law or out of it, in the vaguer sanctions of conscience" (392).

When "our friend the bad man" (393) consults an attorney, he isn't interested in The Law in the abstract: he wants to know what the current law in Massachusetts (or wherever) is. Moreover, since statutes, rules, and precedents are to some degree open-textured and, where they are, may be construed in more than one way, the bad man wants to know, not just what the statutes, etc., say, but how judges can be expected to interpret them. Thus: "The prophecies of what the courts will do in fact, and nothing more 
pretentious, are what I mean by the law" (393). It is this strand of the argument, of course, that is captured in the description of Holmes's approach as "the prediction theory," and-along with the focus on the Bad Man-in the classification of Holmes as proto-legal-realist.

Judges tend to present their rulings and opinions as if they were deductions from general principles-in "logical form," as Holmes says; and often suppose that judicial dissent must be a sign that someone has made a mistake in logic. This, however, is another illusion. To be sure, logic has a place in law; still, a legal system is very different from a set of axioms from which correct decisions may be deduced. ${ }^{53}$ Judicial dissent is unavoidable; for disagreements among judges really turn, not on the formal validity or invalidity of their arguments, but on their substantively different ideas about questions of policy. Thus: "The language of judicial decision is mainly the language of logic. ... [But b]ehind the logical form lies a judgment as to the relative worth and importance of competing legislative grounds, often an inarticulate and unconscious judgment" (397). It is this strand of the argument, of course, that is captured by classifying Holmes's approach under the rubric "the revolt against formalism." 54

Now Holmes can move to higher jurisprudential ground, and present a positive account of the growth and evolution of the law going far beyond thelaw-in-England-in-1215 or the-law-in-Massachusetts-in- $1896 .{ }^{55}$ The first side of this positive account is historical: the intelligent study of its history illuminates the forces that made present law thus and so. This will sometimes reveal, however, that the source of a legal distinction or rule, etc., is to be found in circumstances or procedures which no longer obtain, or that there is no better warrant for a rule we still confidently enforce than that things have always been done this way.

Holmes gives as example the doctrine in English law that "a material alteration of a written contract by a party avoids it as against him" (402); i.e., not only can you not use the writing, but the contract itself is cancelled-a

53. There is a detailed discussion of Holmes's conception of the role of logic in the law in Scott Brewer, "Traversing Holmes's Path toward a Jurisprudence of Logical Form," in "The Path of the Law" and Its Influence: The Legacy of Oliver Wendell Holmes, Jr., ed. Steven J. Burton (Cambridge: Cambridge University Press, 2000), 94-132. But I set these complexities aside for now-hoping to be able to return to them on another occasion-as not directly to my present purposes.

54. Morton G. White, Social Thought in America: The Revolt Against Formalism (1947; New York: Viking Press, 1949).

55. I chose 1215 because this was the date of Magna Carta, and of the fourth Lateran Council, which prohibited priests from participating in in-court tests by ordeal; and 1896 because this was the date of "The Path of the Law." 
doctrine, Holmes argues, explicable only historically. Once upon a time, in the case of a bond specifically, the contract was inseparable from the actual parchment on which it was written; if the document was destroyed or the seal torn off, the obligee could not recover because the bond no longer existed. ${ }^{56}$ Then, contrary to the general tendency of the law, this doctrine was extended to contracts generally.

However, Holmes insists, "this is how we have always done it" is no reason for continuing to do things that way: "[i]t is revolting to have no better reason for a rule of law than that so it was laid down in the time of Henry IV. It is still more revolting if the grounds on which it was laid down have vanished long since ..." (399). ${ }^{57}$ And so the other part of Holmes's positive account is forward-looking: the intelligent study of "the ends which [legal] rules seek to accomplish, the reasons why those ends are desired, what is given up to gain them, and whether those ends are worth the price" (404) can illuminate how the law might best adapt itself to new circumstances.

In considering how well this or that interpretation of a law meets the ends which justified having the law in the first place, Holmes urges that judges look to the social and economic consequences of their rulings: "I think that the judges themselves have failed adequately to recognize their duty of weighing considerations of social advantage. ... I cannot but believe that if the training of lawyers led them habitually to consider more definitely and explicitly the social advantage on which the law they lay down must be justified, they sometimes would hesitate where now they are confident, and see that really they were taking sides upon debatable ... questions" (398). Hence Holmes's dictum that "[f]or the rational study of the law the blackletter man may be the man of the present; but the man of the future is the man of statistics and the master of economics" (399)—which, of course, is the strand of his argument that is captured by enlisting him as precursor of the "law and economics" movement.

However, it isn't only economics Holmes has in mind, but the social sciences generally. He also illustrates the role of considerations of "social advantage" when he asks: "[w]hat better have we than a blind guess to show

56. As, today, there is no obligation to pay if the actual physical check is destroyed (an analogy I owe to Jonnette Watson-Hamilton).

57. Compare this, from Javins v. First National Reality Corporation, 428 F.2d 1071, 1 (1970): "The assumption of landlord-tenant law, derived from feudal property law, that a lease primarily conveyed to the tenant an interest in land may have been reasonable in a rural agrarian society ... . But in the case of the modern apartment dweller, the value of the lease is that it gives him a place to live. ... Some courts have realized that certain of the old rules of property law governing leases are inappropriate for today's transactions." My thanks to Terence Anderson for drawing this case to my attention. 
that the criminal law in its present form does more good than harm?", and urges that judges look to the work of social scientists who are beginning to investigate whether the criminal "is a degenerate, bound to swindle or murder by as deep seated an organic necessity as that which makes the rattlesnake bite," or whether "crime, like normal human conduct, is mainly a matter of imitation" (400). ${ }^{58}$

Now the path from the rocky foothills of Holmes's opening words to the Olympian heights of his final peroration comes into full view; and what looked at first like a passing dismissal of Sir James Stephen's legal analyses"striving for a useless quintessence of all systems, instead of an accurate analysis of one" (403) - stands as a clear signpost. All legal systems are local, specific to a place and time; the idea of "Law-in-Itself" is an illusion. As Holmes would write much later, dissenting in Southern Pacific v. Jensen, "[t]he common law is not a brooding omnipresence in the sky, but the articulate voice of some sovereign or quasi-sovereign that can be identified ... it is always the law of some state." 59 Moreover, every legal system is an artifact of history; all have evolved, grown, adapted (and many have died away) in response to changing social circumstances, pressures, and needs.

And this means that from the very broadest perspective the law-now understood as referring to the whole accumulated history and ongoing evolution of the myriad legal systems of the world-encompasses both the past and the future of the social organization of humanity; in short, of civilization. Holmes returns to this theme over and over:

If your subject is law, the roads are plain to anthropology, the science of man, to political economy, the theory of legislation, ethics, and thus by several paths to your final view of life. ${ }^{60}$

58. Though Peirce doesn't refer to Holmes explicitly, this passage from the Minute Logic of 1902 suggests that he might have been taking notice of Holmes's thinking: "[A]s for public force, let it be restricted to doing what is necessary to the welfare of society. ...[T] punishment of a prison cell ... is not in the least conducive to public or private welfare. As for the criminal classes, I would extirpate them ... by keeping the criminals confined in relative luxury, making them useful, and preventing reproduction ... [making them] self-supporting harmless wards of the state. The only expense would be that of losing our darling revenge upon them." Collected Papers [supra, n.26], 2.164.

59. Southern Pacific v. Jensen, 244 U.S. 205, 222 (1917), Holmes, J., dissenting. (The passage in which this occurs isn't entirely clear on this point, but as I read him Holmes must be contrasting "the law of some state" with Law-in-General, not with federal law.)

60. Holmes, "The Profession of the Law," conclusion of a lecture delivered to undergraduates at Harvard, February 17th, 1886, in Marke, The Holmes Reader [supra, n.1], 678,67 . 
What a subject is this in which we are united,--this abstraction called the Law, wherein, as in a magic mirror, we see reflected not only our own lives, but the lives of all men that have been! ... to the lover of the law ... no less a history will suffice than that of the moral life of his race. ${ }^{61}$

I venerate the law ... as one of the vastest products of the human mind.... It has the final title to respect in that it exists, that it is not a Hegelian dream. (402)

This is how the study of the law "connect[s] with the universe" and may even vouchsafe "a hint of the universal law" (406).

Holmes begins with a down-to-earth, practical view of the law; and, commenting that "a good deal of pretty poor stuff" goes under the name of jurisprudence (403), scoffs at the idea of a "quintessence of all law." Still, we can't classify him as "pragmatic," in the now-current everyday sense of focusing on the practical at the expense of the theoretical; for this would make it impossible to accommodate his emphatic declarations that "theory is my subject, not practical details" (405) and that "[w]e have too little theory in the law rather than too much" (404) ${ }^{62}$ It would be more accurate to say that, while he eschews uselessly free-floating abstractions and respects the practical concerns of the working attorney, Holmes aspires to nothing less than a comprehensive theoretical conception of the law qua ever-evolving human institution.

Holmes urges the tonic effect of looking at the law from the perspective of the Bad Man; acknowledging that this will "stink[] in the nostrils of those who are anxious to get as much ethics into the law as they can" (394), he insists that questions of law not be confused with questions of morals; he believes that judges are often mistaken or self-deceived about the real reasons for their rulings; and he recommends that they look clear-eyed (hard-nosed?), at considerations of "social advantage." So it is no wonder he is seen as "one of the most important forerunners" of the legal realist movement ${ }^{63}$-or that the realists were later to cite him over and over. In 1930, Karl Llewellyn wrote that "rules ... are important so far as they help you see or predict what judges will do or so far as they help you get judges to do something. ... That is all their importance except as pretty playthings; ${ }^{64}$ and, acknowledging Holmes's

61. Holmes, "The Law" [supra, n.1], 62.

62. Compare "Justice Holmes does not succumb to the fashionable but foolish glorification of the practical over the theoretic or contemplative life": Morris R. Cohen, "Justice Holmes" in Mr Justice Holmes, ed. Felix Frankfurter (New York: Coward McCann, 1921), 21-32, 23.

63. I quote from the editors' introduction to the first chapter, "Antecedents," American Legal Realism, ed. Morton J. Horwitz, and Thomas A. Reed (New York: Oxford University Press, 1993), 3.

64. Karl Llewellyn, The Bramble Bush: Our Law and Its Study (New York: Oceana, 1930), 5. 
influence, that "th[e] concept of 'real rule' has been gaining favor since it was first put into clarity by Holmes." In this context-in a phrase startlingly reminiscent of Peirce's criticisms of Descartes's "paper doubts"-Llewellyn contrasts "real" with merely "paper" rules; ${ }^{65}$ and in the same article, reflecting on the interconnections of law and the social sciences, he observes that "Holmes' mind had travelled most of the road two generations back." ${ }^{\text {"T6 }}$ The same year, Jerome Frank described Holmes as "the Completely Adult Jurist."

So perhaps it would be fair to classify the realists as "post-Holmesians." Still, it is important not to forget that Holmes had caught, at the end of what Llewellyn thinks of as his proto-realist path, a glimpse of that "comprehensive theoretical vision of the law qua ever-evolving human institution" stressed in my reading.

\section{Filling SOME POTHOLES IN THE PATH OF THE LAW}

Even if it is plausible to think that a working attorney advising his client the Bad Man is trying to predict what a judge would decide, it seems ludicrous to suppose that this is what the judge himself is doing (though, to be sure, he may try to predict what a higher court might decide were the case to be appealed). This was the objection that came first to my mind; and, as I subsequently discovered, it had been made long before by $\mathrm{Hart}^{68}$ and, decades before that, by Fisch. ${ }^{69}$ But now I see it can be avoided by reading Holmes with a little charity. ${ }^{70}$ Taking the perspective of working attorney and his client the Bad Man is a heuristic device, ${ }^{71}$ a way of highlighting two key contrasts: between law and morality, and between The Law in the abstract and Massachusetts-

65. Karl Llewellyn, "A Realistic Jurisprudence-the Next Step," Columbia Law Review 30.4 (1930) 431-65, 448. Peirce, Collected Papers [supra, n. 26), 5.376 (1877). There are numerous other references in Peirce's writings to the contrast of "paper" with "real" or "living" doubt, but this is the earliest I have been able to find.

66. Llewellyn, "A Realistic Jurisprudence-the Next Step" [supra, n.65], 454.

67. Jerome Frank, Law and the Modern Mind (1930; Gloucester, MA: Peter Smith, 1970), 270.

68. H. L. A. Hart, The Concept of Law (Oxford: Clarendon Press, 1961), 143.

69. Fisch, "Justice Holmes, the Prediction Theory of Law, and Pragmatism" [supra, n.46], 8: "[i]t is inconceivable that in his work as a judge [Holmes] should have thought of law as prediction except with reference to a possible appeal ...."

70. As, in effect, Fisch does when he acknowledges that Holmes is here thinking of the law from the point of view of the practicing lawyer.

71. After I had written this clause, I found that Brewer had also used the phrase "heuristic device" in this context; see "Traversing Holmes's Path toward a Jurisprudence of Logical Form" [supra, n.53], 96. (Earlier, David Luban had considered this interpretation but rejected it-but for what seem to me bad reasons; see Luban, "The Bad Man and the Good Lawyer," New York University Law Review 72 (1997) 1547-83, 1573.) 
law-in-1896 or EC-law-in-2005 in the particular. It highlights a perspective, the Bad Man's, from which what matters isn't what's right, or what "the Will of the Sovereign" is, or even simply what the statutes, etc., say, but what the courts, which are the instruments of the public force, will determine the law to be.

An attorney may well be able to predict that if the Bad Man drives at 39 miles an hour in a 30-mile-an-hour zone he will not be subject to any penalty; but of course this doesn't mean that the speed limit is (say) 40 miles an hour, not 30. So, Luban argues, Holmes's account is "preposterous," missing the obvious fact that a rational Bad Man's risk-benefit analysis would take into account how likely it is that a law will be enforced. ${ }^{72}$ But this objection also misfires. Holmes asks his audience to imagine an attorney advising a client what conduct is legal, not what illegal conduct might go undetected or unpunished - for his purpose is, precisely, to highlight the distinction between law and morality. (Perhaps he would have made this clearer had he written the relevant lines, in the manner of Peirce's revised, more realist, subjunctive version of the pragmatic maxim, in the subjunctive mood, in terms of what courts would decide were the case to come before them.)

More importantly, perhaps, criticisms like these focus on Holmes's first steps; while what is most valuable about "The Path of the Law," as I see it, is the much broader view to which those steps ultimately lead: a view which is all-encompassing, yet not unhelpfully abstract; firmly anchored in real-world institutions and practices-realistic in the ordinary-language sense of the word -yet not cynical; anti-essentialist in eschewing the search for a mythical "quintessence of all law," yet not anti-theoretical. Legal systems are local ${ }^{73}$ one might almost say (but not without appreciating the irony) essentially so; they are, as the jargon of our day would have it, "socially constructed," marked by the contingencies and curiosities of the circumstances in which they originally arose, and by each of the many Pushmepullyou mechanisms at work as they continue to grow and adapt to new circumstances. And yet ... and yet, the continuing history of the evolution of legal systems is the history of humanity's long, ragged struggle towards civilized social life.

To be sure, Holmes's integration of the specific and the general, the local and the global, the humdrum and the inspiring, is a long way from perfect. But

72. David Luban, "The Bad Man and the Good Lawyer" [supra, n.71], 1571.

73. Arthur R. Hogue writes that "the common law, properly so called, is not local custom. It is not ordinarily spoken of as the usage of a locality ... such as the shire of Kent, ... which was permitted to enjoy until 1926 its own peculiar rules of inheritance by gavelkind," but rather "applies throughout the realm" (Origins of the Common Law (Bloomington, Indiana: Indiana University Press, 1966; Indianapolis, Indiana: Liberty Fund, 1986), 187-8). But "throughout the realm" is local, in the sense $I$ intend. 
it is good enough to repay the effort of trying to improve it, to fill some gaps where he seems to have "too little theory rather than too much"-especially where his argument seems, as it stands, covertly to presuppose the kind of purely abstract and essentialist philosophy of law that he officially, and in my opinion rightly, eschews.

Holmes steers clear of questions like "What is Law?", and the pretentiously unhelpful answers they are apt to prompt. It might be objected, however, that when he refers to "the incidence of the public force through the instrumentality of the courts" (391), and assumes that what's relevant is what penalty a judge will impose on the Bad Man, and not, say, what penance his priest will demand or what the boss of the local Mafia family will have his goons do to him, Holmes implicitly takes for granted an answer to this question in terms of-well, of legal institutions. But there is another way of looking at this, more in harmony with the general tenor of Holmes's jurisprudence, that does not invite the essentialist kind of answer he is anxious to avoid.

In the spirit of Holmes's observation that "most differences" are merely differences of degree, "when nicely analyzed," 74 and of the regulative principle Peirce called "synechism"-that hypotheses that posit continuities are to be preferred over hypotheses that rely on sharp dichotomies ${ }^{75}$-I suggest looking at the continuum of systems of social norms from tribal and religious customs, taboos, rules, and penalties through the "illegal legal orders" of the favelas of which Boaventura de Sousa Santos writes, ${ }^{76}$ to the most central, paradigmatic cases of legal systems past and present and the complex, overlapping, and sometimes conflicting meshes of federal and state or provincial legal orders, of national and international law, ... and so forth and so on; and, rather than fussing over which qualify as really, genuinely legal, exploring the respects in which they are like each other, and those in which

74. Rideout v. Knox, 148 Mass. 368,19 N.E. 390 (1889). Holmes's opinion is reprinted in Harry C. Shriver, The Judicial Opinions of Oliver Wendell Holmes: Constitutional Opinions, Selected Excerpts and Epigrams as Given in the Supreme Judicial Court of Massachusetts (1883-1902) (Buffalo, NY: Dennis and Co., 1940), 162-6.

75. Peirce, Collected Papers [supra, n.26], 6.102-163 (1892); see also Susan Haack, "Not Cynicism but Synechism: Lessons from Classical Pragmatism," Transactions of the Charles $S$. Peirce Society 41.2 (Spring 2005) 239-52, also forthcoming in A Companion to Pragmatism, ed. Joseph Margolis and John Shook (Oxford: Blackwell).

76. Boaventura de Sousa Santos, Toward a New Common Sense (New York: Routledge, 1995), especially 158-249. According to my Brazilian informants, however, it is the drug dealers who keep order in the favelas; so perhaps this case is further from the centrally legal, and closer to my example of penalties imposed by the Mafia, than Santos's descriptions might suggest. (There is no entry in the index of Santos's book under "drugs" or "drug dealers"; whether this is because things were different in 1970, the year of Santos' study of the quasi-legal role of the Residents' Association in the favela he calls "Pasargada," I have been unable to determine.) 
they are unlike. ${ }^{77}$ To be sure, this would be a tough job; still, I believe it could tell us everything we really need to know, without trapping us in a metaphysical impasse as the old essentialist question, "What is Law?" is apt to do. ${ }^{78}$

Holmes urges that judges look to considerations of "social advantage," and specifically to the economic consequences of their rulings, but he doesn't seem to tell us where such considerations legitimately apply, or how they are to be weighed against considerations of other kinds. I can find nothing explicit in "The Path of the Law" that distinguishes, say, framing an innocent man to prevent public panic because there's a serial killer on the loose or reincarcerating a sexual predator beyond his sentence to prevent him from committing further crimes, from relying on considerations about incentives and such to hold all manufacturers of a certain type of drug partly liable when it is impossible to determine which of them actually made the drug that harmed these plaintiffs ${ }^{79}$ (or to hold a manufacturer partly liable even when we know they didn't sell the drug that injured this plaintiff); ${ }^{80}$ nor, more

77. Compare the strategy adopted in my Defending Science-Within Reason: Between Scientism and Cynicism (Amherst, NY: Prometheus Books, 2003), ch. 6: rather than asking whether the social sciences are really sciences, exploring and trying to articulate the ways in which they are like the natural sciences, and the ways in which they are unlike.

78. The approach I am recommending has much in common with some ideas expressed in Llewellyn, who writes: "I am not going to attempt a definition of law. ... A focus, a core, a center-with the bearings and boundaries outward unlimited." Karl Llewellyn, "A Realistic Jurisprudence-the Next Step" [supra, n.65], 432. More recently, arguing against "legal centralism" and urging a "centrifugal" over a "centripetal" approach, Galanter has suggested looking at the many and various non-legal means of settling disputes as operating "in the shadow of" the legal system narrowly conceived, which sets a framework for party negotiation by providing "bargaining chips." Marc Galanter, "Justice in Many Rooms: Courts, Private Ordering, and Indigenous Law," Journal of Legal Pluralism 19 (1981) 1-47, citing M. Damaska, "A Foreign Perspective on the American Judicial System," in State Courts: A Blueprint for the Future, ed. T. J. Fetter (Williamsburg, Virginia: National Center for State Courts, 1978), 237-42.

79. For example, in DES (diethylstilbestrol) cases, where the injury-cancers that developed in the daughters of women who had taken the drug during pregnancy-was not apparent until decades after the women's exposure. Sindell $v$. Abbott Laboratories, 26 Cal.3d 588, 612, 607 P.2d 924, 937, 163 Cal.Reptr. 132, 145 (1980) (holding that "[e]ach defendant will be held liable for the proportion of the judgment represented by its share of that market unless it demonstrates that it could not have made the product which caused plaintiff's injuries"). Bichler v. Eli Lilly \& Co., 79 A.D.2d 317, 329, 436 N.Y.S.2d 625, 632 (1981) (holding that "[i]t does not strain one's sense of fairness to allow a limited expansion of the doctrine of concerted action to cover the type of circumstance faced in a DES case where the traditional evidentiary requirements of tort law may be insurmountable").

80. Hymowitz v. Eli Lilly \& Co., 73 N.Y.2d 487, 512, 539 N.E.2d 1069, 1078, 541 N.Y.S.2d 941, 950 (1989) (holding that "there should be no exculpation of a defendant who, 
generally, anything that indicates how Holmes sees considerations of economics or social policy interacting with considerations of liberty, fairness, and equity.

This is in effect the lacuna Benjamin Cardozo noticed when he asked:

Shall we think of liberty as a constant, or, better, as a variable that may shift from age to age? Is its content given us by deduction from unalterable procedures, or by a toilsome process of induction from circumstances of time and place? Shall we say that restraints and experiments will be permitted if all that is affected is the liberty to act, when experiment or restraint will be forbidden if the result is an encroachment upon liberty of thought or speech? ... I do not dare say how Holmes would make answer to these queries or others like them..${ }^{81}$

Like Cardozo, I would elect the less abstract option; and my guess (and I suspect Cardozo's) is that, if pressed, Holmes would, too. Holmes's preference for the vague term "public force" over Austin's "sovereignty" points in this direction. He alludes to "the customs of the Salian Franks ... the German forests, ... the needs of the Norman kings" (399), which reminds us that, while "the Will of the Sovereign" could once be construed as literally referring to the fiat of tribal chieftains or feudal kings, in complex modern societies there is only that diffused, delegated "public force" expressed in the decisions of federal, state, military, and administrative courts, of international tribunals, ... and so on.

Peirce is again helpful; this time, though, it is his conception of the growth of meaning on which we can draw. Thinking about how, as our knowledge grows, scientific concepts become deeper and thicker (and sometimes shed old connotations), the young Peirce had observed "[h]ow much more the word electricity means now than it did in the days of Franklin; how much more the term planet means now than it did in the time of Hipparchus. These words have acquired information. ${ }^{82}$ Later he makes a similar point using a different and more immediately relevant kind of concept as example: "Symbols grow ... . Such words as force, law, wealth, marriage, bear for us very different meanings than those they bore to our barbarous ancestors." ${ }^{83}$ Yes; and concepts like liberty, right, etc., are deepened, thickened, made more specific (and sometimes stripped of old accretions) in the long, ongoing struggle of legal disputes and challenges, interpretations and reinterpretations. They are not

although a member of the market producing DES for pregnancy use, appears not to have caused a particular plaintiff's injury").

81. Benjamin Cardozo, "Mr. Justice Holmes," introduction to Mr. Justice Holmes, ed. Felix Frankfurter [supra, n.62], 1-20, 6-7.

82. Peirce, Collected Papers [supra, n.26], 7.587 (c.1867). The second italics are mine.

83. Peirce, Collected Papers [supra, n.26], 2.302 (c.1895). 
Platonically fixed and uncontestable, but initially thin, schematic concepts inherently open to more and less expansive readings, to finer specification, to broader extrapolation. ${ }^{84}$

Holmes conceives of the law as encompassing all the many and various legal systems, past and present: remember that description of the history of the evolution of the law as disclosing "every painful step and world-shaking contest by which mankind has fought and worked its way from savage isolation to organic social life"; ${ }^{85}$ and he observes that "[a] man may live greatly in the law as well as elsewhere; there as well as elsewhere his mind may find its unity in an infinite perspective ... . "86 This is a grand vision reminiscent of Peirce's conception of science as the long, ongoing struggle of the community of inquirers - the notional community of all those, past, present, and future, who have "storm[ed] the stronghold of truth," each new wave climbing clambering over those who went before ${ }^{87}$ In a speech the year before "The Path of the Law" Holmes had written:

The eternal procession [of generation after generation of lawyers, judges and legal thinkers] moves on, we in the front for the moment; and stretching away against the unattainable sky, the black spearheads of the army that has been passing in unbroken line already for over a thousand years." 88

This has more than a military metaphor in common with Peirce's conception of the human struggle to understand the world.

However, while Peirce makes an intimate connection between truth and inquiry by means of his pragmaticist conception of truth as the hypothetical Final Opinion that would be reached were inquiry to continue indefinitely, and reality as the object of that Final Opinion, ${ }^{89}$ Holmes leaves one wondering

84. From Hymowitz v. Eli Lilly [supra, n.80], 507: " $t$ he ever-evolving dictates of justice and fairness, which are the heart of our common-law system, require formation of a remedy for injuries caused by DES" (emphasis added).

85. Holmes, "The Law" [supra, n.1], 63.

86. Cited in John Dewey, "Justice Holmes and the Liberal Mind" [supra, n.62], 33-45, 35.

87. Peirce, Collected Papers [supra, n.26], 7.51 (undated). The "fortress of knowledge" metaphor is borrowed and adapted from John Locke.

88. Holmes, "Learning and Science," speech given at a dinner of the Harvard Law School Association in honor of Prof. C. C. Langdell, June 25th, 1895, in Marke, The Holmes Reader [supra, n.1], 72-3, 73.

89. So the true and the real, as Peirce defines them, are independent of what you, or I, or any individual think them to be; not, however, of what the hypothetical community of inquirers would think them to be at the end of inquiry. It is also worth noting that Peirce's definitions are not intended to provide any guarantee of steady progress towards or convergence on the truth, or even any guarantee that the truth will actually ultimately be attained. 
how, exactly, he sees the evolution of legal systems as connected with "the moral life of the race."

$* * *$

Some critics have suggested that Holmes's attitude to the relation of law and morality is just inconsistent. ${ }^{90}$ It is, however, entirely consistent to maintain (as Holmes does) that law and morality cannot be identified-that the two are conceptually distinct, that "morally bad, unjust law" is not an oxymoron; and at the same time to hold (as Holmes also does) that there may be greater or lesser overlap in extension between law and morality, and that the evolution of law may constitute progress in a moral sense. But perhaps the critics have in mind, rather, the apparent difficulty of reconciling Holmes's insistence that he "take[s] for granted that no hearer of mine will misrepresent what I have to say as the language of cynicism," his description of the law as "the witness and external deposit of our moral life" (392), and the indications that, by "considerations of social advantage" he means something more like "promoting the good of society" than "favoring the interests of a given social class," with passages that suggest that he thinks might makes right. As I understand him, however, when Holmes writes of (legal) "battle grounds where ... the decision can do no more than embody the preference of a given body in a given place and time" (397), or of the more powerful interests' winning the struggle, what he means is that a legal system is a forum for competing social groups to sort out their conflicts without resorting to brute force. So it might be more accurate to see Holmes's conception of the evolution of the law as fumbling steps on the road to more civilized social life as manifesting a kind of meliorism.

But now it begins to appear that the problem with Holmes's view of the relation of law and morality is not an inconsistency but-ironically enough, given that he is sometimes accused of moral skepticism-a tendency to elide the weak, plausible thesis that the growth of legal systems mirrors the evolution of human social life, tracking moral steps forward and backward, into the much stronger and much less plausible thesis that the history of law is a history of moral progress.

90. See Lon Fuller, The Law in Quest of Itself (1940; Boston: Beacon Press, 1966), 118; Morton White, Social Thought in America [supra, n.54], 69-70; Henry M. Hart, "Holmes's Positivism-An Addendum," Harvard Law Review 64 (February 1951) 929-37, 923. For earlier responses to this criticism see Mark DeWolfe Howe, "Holmes' Positivism-A Brief Rejoinder," Harvard Law Review 64 (February 1951) 937-939, 939, and Frederic Rogers Kellog, The Formative Essays of Justice Holmes: The Making of an American Legal Philosophy (Westport, Conn.: Greenwood Press, 1984), 58-74. 
In early papers on "Primitive Notions in Modern Law," as well as in the first chapter of The Common Law, Holmes points to the ways in which a primitive desire for vengeance, which he takes to be the original basis of law, has gradually been modified and adapted with the growth of civilization. As "an instructive example of the mode in which the law has grown ... from barbarism to civilization," Holmes refers to laws requiring that a slave or an ox that injures someone be stoned or surrendered by the current owner to the victim or his family, and to the provision in the Twelve Tables of Roman Law that an insolvent debtor may be cut up and his body divided among his creditors $;{ }^{92}$ and then describes the ways in which such laws gradually changed and became more rational: "when ancient rules maintain themselves ..., new reasons more fitted to the time have been found for them, and ... they gradually receive a new content, and at last a new form, from the grounds to which they have been transplanted. ... [I]f truth were not often suggested by error, if old implements could not be adjusted to new uses, human progress would be slow." 93 This last observation, like that phrase "from barbarism to civilization," strongly suggests that Holmes was assuming that the evolution of law is a progressive process.

Perhaps he is thinking, in part, that any peaceful means of settling disputes is better than the alternative and, in part, that some sort of stable and predictable legal order is necessary for any kind of civilized life; but obviously neither of these propositions is sufficient to establish a progressivist thesis. In a speech of 1913 Holmes observes that "[i]t is a misfortune if a judge reads his conscious or unconscious sympathy with one side or the other prematurely into the law, and forgets that what seem to be first principles are believed by half his fellow men to be wrong." axioms or first principles discoverable a priori; but, as I read him, he is no moral skeptic, but a moral fallibilist who thinks of ethics in an empirical, experimental way. So one might think of looking to James's moral philo-

91. Holmes, "Primitive Notions in Modern Law," The American Law Review 10 (April 1876) 422-39; "Primitive Notions in Modern Law II," The American Law Review 11 (July 1877) 641-660. These lectures are reprinted in Kellog, The Formative Essays of Iustice Holmes [supra, n.90], 129-46 and 147-66.

92. "Lecture I: Early Forms of Liability," The Common Law (1881), in Novick, Collected Works [supra, n.49], vol. 3, 109-324, 115-34. The relevant provision of the Twelve Tables is III. 2; see http://www.fordham.edu/halsall/ancient/12tables.html. (At first glance these "Tables" might look a lot like a set of legal "axioms"; but on second thoughts the idea that every specific legal decision could be deduced from them seems implausible to say the least.)

93. The Common Law [supra, n.92], 135.

94. Holmes, "Law and the Court," speech at a dinner of the Harvard Law School Association of New York, February 15th, 1913, in Marke, The Holmes Reader [supra, n.1], 646,65 . 
sophy-perhaps noting its affinity with Holmes's conception of "weighing of considerations of social advantage" in terms of accommodating the competing demands of different groups in society-for a more articulate theoretical account that might supply the missing argument.

For in "The Moral Philosopher and the Moral Life," James had argued that, since every desire makes some moral claim, one task of moral philosophy is, so far as possible, to reconcile competing desires: "The actually possible in this world is vastly narrower than all that is demanded; and there is always a pinch between the ideal and the actual, which can only be got through by leaving part of the ideal behind." 95 And Dewey, in effect, amplifies and refines James's account when he shifts the focus from what is actually desired to what is really desirable, genuinely conducive to human flourishing; and, not entirely by the way, argues that economic conditions are not to be despised as "mere" means, but must be taken seriously as important elements in "the construction of good." 96

But even assuming that an empirical, experimental style of moral philosophy such as James's or Dewey's is defensible-which certainly isn't something I can hope to settle here, but a whole other question for a whole other lifetime - there could still be no theoretical guarantee that the evolution of legal systems is bound to be morally progressive; not at every step, and not even by and large and on the whole and in the long run. Outside of those Hegelian dreams to which Holmes dismissively alludes, there can be no guarantee that some class or classes of people will not, in principle or in practice, be denied access to the justice system, or denied any voice in the process by which laws are made; there can be no guarantee against the evolution of oppressive, totalitarian societies and oppressive, totalitarian laws; and there can be no guarantee against the stagnation, or the decline, of civilized social life.

In 1924, in the course of his first attempt, with the help of a GermanEnglish dictionary, to read the first volume of Oswald Spengler's extraordinary, visionary, over-reaching, infuriating rhetorical tour de force, The Decline of the West, ${ }^{97}$ Holmes wrote to Pollock: "when one suspects that a

95. William James, "The Moral Philosopher and the Moral Life" (1891), in Selected Writings: William James, ed. Graham Bird (London: Dent; Rutland, Vermont: Everyman, 1995), 298-319, 310-311.

96. Dewey, "The Construction of Good," The Quest for Certainty (1929; New York: Capricorn Books, G. P. Putnam's Sons, 1960), 254-86, especially 282-3.

97. Oswald Spengler, Der Untergang des Abendlandes, 2. vols. (Vienna: Braumiller, 191822); English translation by Charles Francis Atkinson, under the title The Decline of the West (New York: Knopf, 1926-8). Among the many infuriating charms of this work is the fold-out chronology of the History of Almost Everything at the end of the second volume-which 
man knows something about life that one hasn't heard before one is uneasy ... It is long since I have got so much from a book as this, and if I heard that the swine were dead I should thank God." ${ }^{.98}$ In 1932, after reading both volumes in translation, he wrote again: "the accursed Spengler ... has as swelled a head as man can have and live, but the beast has ideas, many of which I don't know enough to criticize. I wish he were dead." 99 The "beast's" central and essential ideas, of course, were that all civilizations rise and fall, and that Western civilization was then in decline. For all its intellectual failings, for all its rhetorical excesses, Spengler's book must have been deeply unsettling to Holmes's hope that the evolution of the law tracks, not just the "moral life of the race," but the advance of civilization, of moral progress. Perhaps this explains Holmes's startlingly ambivalent reaction, his grudging acknowledgement that he had learned something from the "accursed Spengler"- the swine.

\section{THEORY AND PRACTICE: MR. JUSTICE HOLMES}

I don't believe Holmes was trying to provide a decision-procedure for judges. Since his philosophy of law is anchored in the insight that legal systems are local, it would hardly be appropriate that it aspire to say how a judge here and now (or there and then) should decide (or should have decided) an issue; for judicial decisions are apt to be focused on questions specific to a place, a time, a legal history, and a social context. So while some may take its failure to supply such a decision-procedure as an objection to Holmes's philosophy of law, I do not. Skimming through the list of Holmes's own thousand-odd opinions, what strikes me is, first, the sheer variety and the narrow specificity of the issues involved-the power of the Massachusetts legislature to grant woman suffrage; ${ }^{100}$ the restoration of remedies extinguished by lapse of time; ${ }^{101}$ the right of the legislature to limit the height of boundary fences; ${ }^{102}$ the right of the state to kill diseased horses; ${ }^{103}$ the doctrine

predicts, among other things, the year in which science will come to an end: 2000 (!).

98. Holmes to Pollock, July 18th, 1924, in Howe, Holmes-Pollock Letters [supra, n.41], 139.

99. Holmes to Pollock, May 15th, 1932, in Howe, Holmes-Pollock Letters [supra, n.41], 309.

100. In re Municipal Suffrage to Women, 160 Mass. 586, 36 N.E. 488 (1894); Holmes's opinion is reprinted in The Judicial Opinions of Oliver Wendell Holmes [supra, n.74], 6-9.

101. Dunbar v. Boston and Providence R. R. Corp, 181 Mass. 383, 63 N.E. 916 (1902); Holmes's opinion is reprinted in Shriver, The Judicial Opinions of Oliver Wendell Holmes [supra. n.74], 44-47.

102. Rideout v. Knox, 148 Mass. 368 (1889); Smith v. Moore, 148 Mass. 407, 19 N.E. 393 (1889); Holmes's opinion is reprinted in Shriver, The Judicial Opinions of Oliver Wendell 
of "attractive nuisance"; 104 the constitutionality of laws restricting hours of work, ${ }^{105}$ etc., etc., etc. - and then the near-impossibility of understanding Holmes's arguments without reference to the legal setting and the social circumstances in which they arose.

However, two themes that recur in Holmes's constitutional opinions may have an indirect bearing on my interpretation of "The Path of the Law." The first is that, while the Constitution has its roots in the past, it is intended for an unknown future. As Holmes wrote in Gompers:

the provisions of the Constitution are not mathematical formulas having their essence in their form; they are organic living institutions ... . Their significance is vital not formal; it is to be gathered not simply by taking the words and a dictionary, but by considering their origin and their line of growth. ${ }^{106}$

\section{And in Missouri v. Holland:}

[W] hen we are dealing with words that are also a constituent act, like the Constitution of the United States, we must realize that they have called into life a being the development of which could not have been foreseen completely by the most gifted of its begetters. It was enough for them to realize or to hope that they had created an organism; it has taken a century and has cost their successors much sweat and blood to prove that they created a nation. The case before us must be considered in the light of our whole experience and not merely in that of what was said a hundred years ago. ${ }^{107}$

The second theme is that the Constitution leaves open the possibility of experiment, of trial and error. ${ }^{108}$ This theme is expressed particularly clearly in Holmes's dissent in a 1921 picketing-law case, Truax v. Corrigan:

There is nothing I more deprecate than the use of the Fourteenth Amendment beyond the absolute compulsion of its words to prevent the making of social experiments that an important part of the community desires, in the insulated

Holmes [supra, n.74], 167-8.

103. Miller v. Horton, 152 Mass. 540, 26 N.E. 100 (1891); Holmes's opinion is reprinted in Shriver, The Judicial Opinions of Oliver Wendell Holmes [supra, n.74], 171-80.

104. United Zinc and Chemical Co. v. Britt, 258 U.S. 268 (1922). On the concept of "attractive nuisance," compare Sioux City \& Pac. R.R. Co v. Stout, 84 U.S. 657 (1873); Union Pac. Ry. Co. v. McDonald, 152 U.S. 262, (1894); Erie R.Co. v. Hilt, 247 U.S. 97, (1918).

105. Lochner v. New York, 198 U.S. 45 (1905).

106. Gompers v. United States, 233 U.S. 604, 610 (1914).

107. Missouri v. Holland, 252 U.S. 416, 433 (1920).

108. One might wish that Holmes had said more about how it is to be determined whether states' experiments have succeeded or failed, and what should be done after we have learned from them. 
chambers afforded by the several states, even though the experiments may seem futile or even noxious to me ... ${ }^{109}$

Of course, the same theme was heard, many years before, in one of Holmes's most celebrated opinions, his dissent in Lochner (1905). The majority had ruled legislation that limited bakers' working hours to no more than 10 a day or 60 a week unconstitutional: it "necessarily interferes with the right of contract between the employer and the employee." ${ }^{110}$ In dissent Justice Harlan, with Justices White and Day, argued that "the liberty of contract may ... be subjected to regulations ... [to] guard the public health," and that bakery work was so strenuous, hot, and dusty that the restriction of hours was justifiable on public-health grounds. But Holmes's dissent not only observes that "[a] reasonable man might think it a proper measure on the score of health"; it also stresses states' freedom to experiment: ${ }^{111}$

This case is decided upon an economic theory which a large part of the country does not entertain. If it were a question whether I agreed with that theory, I should desire to study it further and long before making up my mind. But I do not conceive that to be my duty, because I strongly believe that my agreement or disagreement has nothing to do with the right of a majority to embody their opinions in law. ...[A] constitution is not intended to embody a particular economic theory ... . [I]t is made for people of fundamentally differing views ${ }^{112}$

I don't believe it is too fanciful to see this theme as having some connection with (though it is obviously not entailed by) Holmes's conception of the law as a forum for resolving the inevitable struggles between social groups in a peaceful way-nor, probably, as also having something to do with his personal experience of the horrors of the Civil War. ${ }^{13}$

109. Truax v. Corrigan, 257 U.S. 312, 344 (1921). In the same dissenting opinion, Holmes writes that "[d]elusive exactness is a source of fallacy throughout the law." Id. at 342.

110. Lochner [supra, n.105] at 541.

111. It may be worth noting, however, that in Missouri v. Holland Holmes had written that while "no doubt the great body of private relations usually fall within the control of the State, ... a treaty may override its power." Missouri v. Holland [supra, n.107], 434.

112. Lochner [supra, n. 105] at 546. I note that here Holmes does not, as one might have expected-and as his fellow-dissenters do-rely on his assessment of the social and economic consequences of ruling one way or the other. I also note the observation, later in his dissent, that "general propositions do not decide concrete cases. The decision will depend on a judgment or intuition more subtle than any articulate major premise." Id. at 547.

113. Holmes served for three years in the Union army. In the first two years, as a Lieutenant in the Twentieth Massachusetts Volunteer Infantry, he "was wounded three times [at Ball's Bluff, Antietam, and Fredericksburg], twice near fatally, and suffered from dysentery" (Sheldon Novick, "A Brief Biography of Justice Holmes," in Collected Works of Justice Holmes [supra, 
By the end of his long life, Mr. Justice Holmes, the "Yankee from Olympus,"114 stood high in the public esteem. A volume celebrating his ninetieth birthday (the volume in which Cardozo raised his important question about the fixity or flexibility of legal concepts) included a notable tribute from Dewey entitled "Justice Holmes and the Liberal Mind." Though Holmes had "no social panacea to dole out, no fixed social program, no code of fixed ends," Dewey wrote, he was profoundly committed to "[l]iberalism as a method ... the adoption of the scientific habit of mind in application to social affairs"; that he adopted this scientific habit of mind as a judge, in restricted legal contexts, in no way lowered the value of his work "as a pattern of the liberal mind in operation." "And on Holmes's death, in 1935, the New York Times described him as "the chief liberal of [the] supreme bench for 29 years." "16

Since then, however, many have come to believe Holmes's reputation undeserved-a triumph of magnificent literary style over miserable judicial substance-and to criticize his judicial opinions as conservative, narrowminded, benighted, or worse. ${ }^{117}$ Between 1941 and 1943, a series of articles linked Holmes's philosophy with totalitarianism; ${ }^{118}$ in 1945, Ben Palmer popularized these criticisms in the American Bar Association Journal under the title, "Hobbes, Holmes, and Hitler."119 In 1950, an article in the Boston American described Holmes as a "cynical and senile brutalitarian." ${ }^{120}$ More

n.49], 8-17, 9). It may also be worth noting that in Buck v. Bell, 274 U.S. 200, 207, (1927), his most notorious opinion, Holmes writes that the sacrifice asked of Carrie Buck, the retarded woman whom the State of Virginia wished to have sterilized, is not so great compared with that asked of those who are required to die for their country.

114. I allude, of course, to Catharine Drinker Bowen's fictionalized life of Holmes, Yankee from Olympus (Boston: Atlantic/Little Brown, 1944). The play by Emmett Laverty based on the novel, and the subsequent motion picture, are entitled The Magnificent Yankee.

115. John Dewey, "Justice Holmes and the Liberal Mind," in Frankfurter, Mr. Justice Holmes [supra, n.87], 34-5. See also James Tufts, "The Legal and Social Philosophy of Mr. Justice Holmes," American Bar Association Journal 7 (1921), 359; and Roscoe Pound, “Judge Holmes's Contributions to the Science of Law," Harvard Law Review 34 (1921) 449-453.

116. The New York Times (March 6, 1935), section 1, p.1, columns 2-3.

117. The story is well told in G. Edward White, "The Rise and Fall of Justice Holmes," The University of Chicago Law Review 39 (1971) 51-77, which is my source for some of the information in this and the previous paragraph.

118. Francis Lucey, "Jurisprudence and the Future Social Order," Social Science 16(1941), 211-217 ; John Ford, "The Fundamentals of Holmes's Juristic Philosophy," Fordham Law Review 11 (1942) 255-278; Paul Gregg, "The Pragmatism of Mr. Justice Holmes," Georgetown Law Journal 31 (1943) 262-295.

119. Ben W. Palmer, "Hobbes, Holmes, and Hitler," American Bar Association Journal 31 (1945), 569-73.

120. Westbrook Pegler, "Fair Enough,” Boston Evening American (December 18, 1950), 34, 
recently, in 1997, Louise Weinberg wrote of the "littleness" of Holmes's judicial work;, ${ }^{121}$ and when, in 2000, Albert Alschuler asked, "Would you have wanted Holmes for a friend?"'122 it was obviously a question-expecting-theanswer-"absolutely not!"

Whom one would have wanted as a friend really isn't the point. Still, it's an intriguing question. Reflecting on it, I suspect I might well have found Holmes too Olympian for my taste; as, it seems, James eventually came to find him $^{123}$ - not surprisingly, for James manifests a sympathetic understanding of human foibles, and of the suffering caused to some individuals by even the most benign social institutions, nowhere to be found in Holmes's; for example this, from "The Moral Philosopher and the Moral Life":

The pinch is always here. Pent in under every system of moral rules are innumerable people whom it weighs upon, and goods which it represses; and these are always rumbling and grumbling in the background ... . See the abuses which the institution of private property covers ... the unnamed and unnameable sorrows which the tyranny, on the whole so beneficent, of the marriage institution brings to so many ... the wholesale loss of opportunity under our regime of so-called equality and industrialism ... . See our kindliness for the humble and the outcast, how it wars with the stern weeding-out which until now

35 and 45. (On p.34 Pegler writes that "The Harvard Law Review has inquired for the date of the essay in which I referred to the late Oliver Wendell Holmes as a cynical and senile brutalitarian. Let them look it up. I don't think I like them." I don't know whether the Harvard Law Review succeeded, but I have not been able to locate the essay to which he refers.) On the first page of his biography, entitled Pegler, Angry Man of the Press (c.1963: Westport, Conn: Greenwood Press, 1973), after reporting that Pegler was awarded a Pulitzer prize and had "an income exceeding that of the President of the United States," Oliver Pilat reassures readers that "[d]espite frequent insinuations that he must be unbalanced, [Pegler] was sane by ordinary medical and legal standards."

121. Louise Weinberg, "Holmes's Failure," Michigan Law Review96(December 1997) 691723, 691. Not so incidentally, Weinberg reads "The Path of the Law" simply as "a manifesto of American legal realism" (p.696).

122. Albert W. Alschuler, Law Without Values: The Life, Work, and Legacy of Justice Holmes (Chicago: University of Chicago Press, 2000); the question is the title of his chapter 3.

123. Though they were at one time close friends, only a few months after James had written to Holmes as "my Wendly boy," he was complaining that Holmes's "logical and orderly mode of thinking" made him uncomfortable to be with; and a year or so later, he wrote to his brother Henry of Holmes's "cold-blooded, conscious egotism and conceit." The first quotation is from a letter from James to Holmes dated January 3rd, 1868, in Ralph Barton Perry, The Thought and Character of William James, 1 (Boston: Little, Brown, 1935), 508; the second from a letter from James to Holmes dated May 15th, 1868, in Perry, ibid, p.514; and the third from a letter from William to Henry James dated October 2nd, 1869, in Perry, ibid, p.307. My source is Alschuler, Law Without Values [supra, n.122], 36 and 216-7. 
has been the condition of every perfection in the breed. See everywhere the struggle and the squeeze. ${ }^{124}$

"Detachment": this is Rosal Yogat's word for what he finds disturbing about Holmes the man; ${ }^{125}$ and perhaps it is the mot juste.

When one turns to the controversies over Holmes's judicial practice, the first conjecture that comes to mind is that his admirers are simply focusing on different opinions from those that draw his detractors' attention: the admirers, probably, focus on his dissenting opinions in cases like Lochner and Abrams (where, in a memorable defense of the right to free speech, Holmes protested the imposition of a twenty-year sentence for the publication of "two leaflets that I believe the defendants had as much right to publish as the Government had to publish the Constitution ... now vainly invoked by them"); ${ }^{126}$ while the detractors focus on his rulings in cases like $B$ ritt ${ }^{127}$ and, invariably, Buck v. Bell, with that memorably grim line: "[t]hree generations of imbeciles are enough." ${ }^{28}$ Still, given that Frankfurter quotes from Buck v. Bell, including this very line, in the course of his admiring essay on "Justice Holmes and the Constitution," 129 this can't be the whole story. Holmes's defenders argue that critics unfairly ignore the vast differences between the circumstances of his day and of ours; $;{ }^{130}$ his critics point out, in reply, that Holmes was sometimes at odds with more progressive colleagues on the Court.

I'm not going to get embroiled in these controversies; but I will suggest that part of the problem, probably, is that since Dewey wrote his tribute there has been a significant shift not only in the extension but apparently also in the meaning of the word "liberal." What Dewey had in mind in calling Holmes a great liberal was, evidently, his willingness to allow the states to make social experiments. Nowadays, however, while the upshot Holmes favored in

124. James, "The Moral Philosopher and the Moral Life" [supra, n.95], 313-4. (I say that this is "nowhere" found in Holmes; but of course it would have been more accurate to say, "to my knowledge, nowhere ....")

125. Rosal Yogat, "Mr. Justice Holmes: Some Modern Views," University of Chicago Law Review 31.2 (1964) 213-56.

126. Abrams v. United States, 250 U.S. 616, 629 (1919).

127. Britt [supra, n. 104], 268.

128. Buck v. Bell, 274 U.S. 200, 207 (1927).

129. Felix Frankfurter, "Justice Holmes and the Constitution," in Frankfurter, ed., $M r$. Justice Holmes [supra, n.62], 46-119, p.99.

130. It may be worthy of note that the ruling in Buck v. Bell is less than two pages long, and that only one justice dissented. According to George Will, "A Debate that Does not End," Newsweek (July 4th, 2005), 60, by 1935 thirty-five states had compulsory sterilization laws (he doesn't give references, of course, and I have not yet been able to confirm or disconfirm his figure). 
Lochner would be thought of as liberal, his reasoning would likely be perceived as conservative, as illiberal. ${ }^{131}$ I suspect there is a fascinating historico-socio-legal-linguistic-story to be told about when and how this shift took place, ${ }^{132}$ and about the much larger process of which it is probably part, a larger process in which older understandings of right, liberty, etc., have been contested and expanded over and over (and doubtless, also, a fascinating psycho-philosophical story about why Holmes didn't, like Cardozo, see any of this coming). Telling these stories, however, is beyond my present powers; and it is time, anyway, to return to the issues about the meaning of "pragmatism" with which I began.

\section{CONCLUDING THOUGHTS ON THE OLD LEGAL PRAGMATISM AND THE NEW}

"Was Holmes really a pragmatist?"133_bad question. We know that Holmes didn't officially ally himself with pragmatism, and that he had reservations about some of Peirce's and, especially, James's ideas; we know that there were many other influences on his thinking-among them Mill, Bentham, Austin, etc., etc.. But we should also be aware of the many affinities

131. Very recently, dissenting from the majority in a recent Supreme Court case on the medical use of marijuana, Justice Thomas-hardly regarded as a liberal-writes:

[T] he majority prevents states like California from devising drug policies that they have concluded provide much needed respite to the seriously ill. ... Our federalist system, properly understood, allows California and a growing number of other states to decide for themselves how to safeguard the health and welfare of their citizens.

Gonzalez v. Raich, 125 S.Ct. 2195, 2238 (2005).

132. I take it that "liberal" does not, like "progressive" and "conservative," have any inherently indexical character; which is why I think there may be a shift in meaning, not only in reference. To judge by the interesting discussion in Palmer, "Hobbes, Holmes, and Hitler" [supra, n.119], some elements of the shift seem already to have been on the way by 1945. Robin L. West, "Liberalism Rediscovered: A Pragmatic Definition of the Liberal Vision," University of Pittsburgh Law Review 46 (1985) 673-738 and Laura Kalman, The Strange Career of Legal Liberalism (New Haven: Yale University Press, 1996) are focused on more recent developments.

133. Student Note, "Holmes, Peirce, and Legal Pragmatism," The Yale Law Journal 84 (1975) 1123-1140, and Hantzis [supra, n.5] argue affinities between Holmes and Peirce. Thomas Grey, "Holmes and Legal Pragmatism," Stanford Law Review 41 (1989) 787-870, argues affinities between Holmes and Rorty. H. Pohlman, Justice Oliver Wendell Holmes and Utilitarian Jurisprudence (Cambridge: Harvard University Press, 1984), and Patrick J. Kelley, "Was Holmes a Pragmatist? Reflections on a New Twist to an Old Argument," Southern Illinois Law Journal 14 (1990) 427-67, argue Holmes's affinities with utilitarian positivism. (It may be worth noting that Peirce describes pragmatism as a kind of "prope-positivism," i.e., as broadly akin to Comte's ideas, though far more tolerant of metaphysics than classical positivism. See Collected Papers [supra, n.26], 5.423 (1905).) 
of Holmes's thinking with ideas from the classical pragmatist tradition in philosophy-affinities which, as we can now see, go far beyond the similarity between his articulation of the working attorney's conception of what it means to say that the current law in Massachusetts is thus and so, and Peirce's of what it means to say that this diamond is hard, that this proposition is true, or that this thing or kind or natural law is real. ${ }^{134}$

Peirce criticizes the Cartesian notion of intuitive certainty and describes himself as a "contrite fallibilist, ready to dump the whole cartload of his beliefs the moment experience is against them"; ${ }^{135}$ Dewey mounts a sustained attack on the Platonic, as well as the Cartesian, "quest for certainty"; 136 Holmes observes that "certainty generally is an illusion ... no concrete proposition is self-evident" (397). Peirce objects that Descartes' epistemology, which makes the individual the judge of truth, is "viciously individualistic," and contrasts it with the method of science, which relies on interpersonal, objective standards; Holmes contrasts the objective, external legal use of terms like "malice" or "intent" with their subjective, moral use. ${ }^{137}$ Peirce complains about the arguments of moral philosophers and theologians: "it is not the reasoning that determines what the conclusion shall be, but the conclusion that determines what the reasoning shall be. This is sham reasoning", ${ }^{138}$ Holmes writes that judges think they are calculating legally-correct answers when really they are relying on perhaps unconscious policy preferences. Peirce writes to James that "it is of the very essence of [pragmatism] that belief is expectation of the future in all cases," 139 and Dewey observes that pragmatism "does not insist upon antecedent phenomena, but upon consequent phenomena, ... the possibilities of action"; ${ }^{140}$ Holmes's philosophy of law is forward-looking, calling for judges to "consider and weigh the ends of legislation, the means of attaining them, and the cost" (403). In the context of his agapism, a cosmological theory of how order might evolve from chaos, Peirce writes of "the law of mind": "ideas tend to spread continuously and to affect certain others that stand to them in a peculiar relation of

134. Peirce, "How to Make Our Ideas Clear," Collected Papers [supra, n.26], 5.388-410 (1878).

135. Peirce, Collected Papers [supra, n.26] 1.11 (c.1897).

136. John Dewey, The Quest for Certainty [supra, n.96].

137. Cf. Note, "Holmes, Peirce, and Legal Pragmatism" [supra, n.133], 1126-1134. What Holmes means when he writes of morality as "subjective," I believe, is not that what is right depends on what a person thinks is right, but that moral appraisal must refer to inner, mental states such as intentions and the like.

138. Peirce, Collected Papers [supra, n.26], 1.57 (c.1896).

139. Peirce, Collected Papers [supra, n.26], 8.294 (1940).

140. John Dewey, "The Development of American Pragmatism," in Philosophy and Civilization (New York: Putnam, 1931; Capricorn edition, 1963), 13-35, 24. 
affectibility"; ${ }^{141}$ Holmes writes that "[t]he development of our law has gone on for nearly a thousand years, like the development of a plant, each generation taking the next step, mind, like matter, simply obeying a law of spontaneous growth" (398). In short: Holmes may not be officially on the team, but there is certainly much of the spirit of classical pragmatism in his thinking. ${ }^{142}$

"Is contemporary legal neo-'pragmatism' really pragmatism?"-another pretty fruitless question. Despite her Foucauldian fogginess, Alberstein is undeniably correct on one point: the discourse of legal pragmatism from Holmes to the present has hardly been univocal. Holmes's philosophy of law eschews free-floating abstractions, and disavows the search for necessary and sufficent conditions that specify the essence of all law; but, like the philosophy of the classical pragmatist tradition, it is deeply theoretical. So it is far removed from the anti-theoretical stance of many contemporary legal neo-pragmatists.

And by now we can discern, in the mix of overlapping and competing recent conceptions of legal pragmatism, elements of pragmatism in its (present) ordinary-language sense; elements derived from the classical pragmatist tradition in philosophy; and elements from Rortyesque neopragmatism-which is in virtually every important respect diametrically opposed to Peircean pragmaticism. ${ }^{143}$ Moreover, the philosophical elements from classical pragmatism include, at least as often as pragmatism-as-method, specific philosophical doctrines such as James's or Dewey's conception of truth, ${ }^{144}$ or Dewey's political philosophy, ${ }^{145}$ as well as elements of Holmes's jurisprudence ${ }^{146}$-often, however, in simplified, and sometimes in distorted, forms. Nor is it a simple matter of each writer taking one or another of these elements as key; most, apparently, have drawn on several.

Things are further complicated because those who appeal to Peirce's or James's or Dewey's conceptions of truth don't always seem to realize that their concerns were far removed from legal propositions (and because those who appeal to Rorty's cynicism about truth-or, as he prefers to say, holding

141. Peirce, Collected Papers [supra, n.26], 6.103 (1902).

142. In this regard Kellog's approach in The Formative Essays of Justice Holmes [supra, n.90], seems to be somewhat in the same spirit as mine.

143. See Susan Haack, "'We pragmatists ...'; Peirce and Rorty in Conversation" (1997), reprinted in Haack, Manifesto of a Passionate Moderate: Unfashionable Essays (Chicago: University of Chicago Press, 1998), 31-47, and in Pragmatism, Old and New [supra, n.35].

144. See, for example, Tamanaha, Realistic Socio-Legal Theory [supra, n.15], and "A Pragmatic Response to the Embarrassing Problems of Ideology Critique in Socio-Legal Studies," in Morales, Ranascent Pragmatism [supra, n.19], 49-71.

145. See, for example, Posner, Law, Pragmatism, and Democracy [supra, n.18], 99-115.

146. See, for example, William G. Weaver, 'The 'Democracy of Self Devotion': Oliver Wendell Holmes, Jr., and Pragmatism," in Morales, Renascent Pragmatism [supra, n. 19], 3-30. 
the concept at arms' length, "truth"-don't always seem to realize how thoroughly this cynicism undermines the very idea of justice); ${ }^{147}$ by the wretchedly ambiguous use of "foundationalism" and "anti-foundationalism" encouraged by Rorty in epistemology, ${ }^{148}$ and extrapolated by legal scholars to jurisprudence; and by a persistent false equation of "anti-essentialist" and "anti-abstraction" with "anti-theoretical."

The conceptual trap set by "foundationalism" and "anti-foundationalism" is, in brief, this. In epistemology, "foundationalism" has at least three senses; in the first, it refers to a family of theories of epistemic justification characterized by their reliance on a distinction between basic ("foundational") and derived beliefs; in the second, to a conception of epistemology as an a priori discipline the task of which is to provide the foundation of all legitimate claims to knowledge; and in the third, to the idea that our standards of better and worse evidence, more and less justified beliefs, must be, not merely conventional, but grounded in some relation of justification and truth. Only the third has an analogue in legal theory: the idea that legal rules, to be (in a non-epistemic sense) justified, must be grounded in some relation to (presumably, moral) values. But Holmes's account is not clearly antifoundationalist in this sense: while it repudiates the idea that what the law is may be deduced from some overriding set of moral principles, it also urges that judges look to the social benefits and disadvantages of their rulings, and it is if anything over-optimistic about the connection between the evolution of law and moral progress.

The false equation of "anti-essentialist" and "anti-theoretical" has been compounded by some unhappy developments in the use of the word "theory": a too-ready assumption that "theory" must mean "moral, social or political theory" (which are really only a couple of sub-classes of the vast variety of types of theory); and, relatedly, the specialized sense recently taken on by "Theory"-now with that imposing upper-case " $T$ "- - to connote this or that (feminist, postcolonialist, etc.) principle for "reading" literary or legal texts.

Returning to my opening quotations, we see that, like Atiyah, Schneider and Ingram are apparently using "pragmatism" in its ordinary-language rather than its philosophical sense; that Leiter has apparently misconstrued the purport of Holmes's description of the law as involving "prophecies" of what judges will decide; ${ }^{149}$ and that Grey, Posner, and Tamanaha apparently assume

147. See Susan Haack, "Epistemology Legalized: Or, Truth, Justice, and the American Way," The American Journal of Jurisprudence 49 (2004) 43-61.

148. See Susan Haack, Evidence and Inquiry: Towards Reconstruction in Epistemology (Oxford: Blackwell, 1993), chapter 9, for disambiguation.

149. Leiter refers readers to my "Pragmatism," in A Companion to Epistemology, ed. Jonathan Dancy and Ernest Sosa (Oxford: Blackwell, 1992), 351-6, and to Richard Warner, 
that legal pragmatism must be anti-theoretical because it is anti-essentialist. But Luban's formula, "result-oriented, historically-minded antiformalism," briefly captures some key elements of Holmes's jurisprudence quite well; and Tamanaha's reference to the "middle way" captures something important to the tenor of the old-pragmatist tradition.

$* * *$

In 2004, concluding my brief history of the fragmentation of philosophical pragmatism, I wrote that:

[i]t is easy to get hung up on the question of which variants qualify as authentic pragmatism; but probably it is better-potentially more fruitful, and appropriately forward-looking - to ask, rather, what we can borrow from the riches of classical pragmatism, and what we can salvage from the intellectual shipwreck of the new. ${ }^{150}$

Here, exploring the fragmentation of legal pragmatism, I have suggested a reading of Holmes's conception of law informed by ideas from the classical pragmatist tradition in philosophy: an interpretation in which "The Path of the Law" leads us to a comprehensive theoretical vision of the law as a vast congeries of legal systems, each local to its place and time, and all responding, some more and some less successsfully, to human needs and to the conflicts that inevitably arise in any society. ${ }^{151}$

\footnotetext{
"Why Pragmatism? The Puzzling Place of Pragmatism in Critical Theory" [supra, n. 13] "for sturdier and more substantial accounts of pragmatism, with affinities to my own." Leiter, "Rethinking Legal Realism" [supra, n.16], 303, n.156. Leiter's "more substantial" is apparently intended in contradistinction to the idea that pragmatism is trivial or banal, as suggested by Richard Rorty in "The Banality of Pragmatism and the Poetry of Justice," Southern California Law Review 63 (1990) 1811-1820, and Thomas Grey in "Holmes and Legal Pragmatism" [supra, n.132]. But while it is true that neither I nor Warner interpret pragmatism as empty or banal, Leiter's suggestion that our conceptions of pragmatism are akin to his is mistaken: Warner's understanding of pragmatism is quite different from mine; and neither his nor my understanding of pragmatism is even close to Leiter's.
}

150. Haack, "Pragmatism, Old and New" [supra, n.35], 34.

151. My thanks to Mark Migotti for helpful comments on more than one draft, and to John Finnis for helpful suggestions on a near-final version; to David Hollander, in the University of Miami Law Library, for his help in tracking down relevant materials; to Robert Lane, for his help in finding Peirce's earliest uses of the word "pragmatism" and of the phrase "paper doubts"; and to all the colleagues who made helpful comments and suggestions when I presented an earlier version of this paper at the UM Law School Faculty Workshop in September 2005 . 